\title{
PENGARUH PENGGUNAAN STIMULAN GAS TERHADAP PRODUKSI DAN KARAKTER FISIOLOGI KLON BPM 24
}

\author{
Effect of Gas Stimulation on Production and Physiology Characters of BPM 24 Clone
}

\section{Eva HERLINAWATI dan KUSWANHADI}

Balai Penelitian Sembawa, Pusat Penelitian Karet Jalan Raya Palembang - P. Balai KM 29, PO BOX 1127 Palembang 30001

Diterima tgl 17 Juli 2012 / Disetujui tgl 20 September 2012

\begin{abstract}
Ethephon or ethylene gas stimulation has been widely used by rubber plantation to increase production of latex. The mechanism of stimulant with ethephon active ingredient in rubber plant is by decomposing the stimulant into ethylene, hydrochloric acid, and phosphoric acid. Ethephon stimulation has an indirect effect, viz. production increase for less than 50\%. Whereas, gas stimulant can be directly absorbed by the tree with large quantities and result in higher production compared with ethephon. The aim of this experiment was to study the effect of frequency of gas stimulant on production, physiology characters, vegetative growth, and sensitivity to panel dryness. The right and optimum frequency of stimulant will increase productivity without negative effect on latex cell metabolism. The experiment was carried out at Sembawa Research Station from October 2010 until September 2011. The experiment was arranged in a randomized complete-block design with five treatments and four replications, using BPM 24 clones 13 years old planted in 1997. The tapping of trees have been done since 2002 with tapping system S/2 d3 ET2.5\% 10/y (m). The treatments were $S / 4 U$ d3 6d/7 ETG 40/y (w), S/4 Ud3 6d/ 7 ETG 20/y (2w), S/ 4 Ud3 6d/ 7 ETG $10 / y(m), S / 4 U d 36 d / 7$ ET2.5\% $40 / y(w)$, and $S / 4 U d 36 d / 7$ ET2.5\% $20 / y$ $(2 w)$. The result showed that optimum frequency of gas stimulant could increase production without negative effect on plant health. Gas stimulant could increase production about $66.1 \%-76.2 \%$ when compared with ethephon $S / 4 \quad U d 3 \quad 6 d / 7$ ET2.5\% 20/y (2w). Based on the observation of the production, physiological condition and
\end{abstract}

plant health, gas filling into the applicator was every two weeks and the panel was changed every three months to avoid decline in production due to "exhaustion" of panel tapping.

Keywords:Hevea brasiliensis, latex, tapping system, gas stimulation, production, physiological condition, ethylene, ethephon

\begin{abstract}
Abstrak
Penggunaan stimulan seperti etefon atau gas etilen telah banyak diterapkan terutama pada perkebunan karet untuk meningkatkan produksi lateks. Mekanisme kerja stimulan yang berbahan aktif etefon dalam tanaman karet yakni terdekomposisi menjadi etilen, asam hidroklorit, dan asam fosfat. Stimulan dengan bahan aktif etefon berpengaruh tidak langsung, peningkatan produksi hanya mencapai kurang dari $50 \%$. Sementara itu stimulan dengan bahan aktif berupa gas etilen diabsorbi langsung oleh batang tanaman karet dengan jumlah yang lebih banyak dan memberikan produksi yang lebih tinggi dibanding etefon. Penelitian ini bertujuan untuk mengetahui pengaruh frekuensi sistem stimulan gas terhadap produksi, karakter fisiologi, pertumbuhan vegetatif, dan kepekaan terhadap kering alur sadap. Frekuensi stimulan yang tepat dan optimum akan memberikan produksi tinggi, tanpa menimbulkan efek negatif terhadap metabolisme sel lateks. Penelitian dilaksanakan di Kebun Percobaan Balai Penelitian Sembawa mulai Oktober 2010
\end{abstract}


sampai September 2011. Penelitian disusun berdasarkan Rancangan Acak Kelompok dengan lima perlakuan sistem sadap dan empat ulangan, menggunakan klon BPM 24 tahun tanam 1997 berumur 13 tahun. Penyadapan telah dilakukan sejak 2002 dengan sistem sadap S/2 d3 ET2,5\% $10 / \mathrm{y}(\mathrm{m})$. Perlakuan antara lain $\mathrm{S} / 4 \mathrm{U} \mathrm{d} 3$ 6d/7 ETG 40/y (w), S/4 U d3 6d/7 ETG 20/y (2w), S/4 U d3 6d/7 ETG 10/y (m), s/4 U d3 6d/7 ET2,5\% 40/y (w), dan S/4 U d3 6d/7 ET2,5\% 20/y (2w). Hasil penelitian menunjukkan dengan frekuensi stimulan gas yang tepat diharapkan produksi tanaman karet dapat ditingkatkan tanpa menimbulkan pengaruh negatif terhadap kesehatan tanaman. Stimulan gas dapat meningkatkan produksi sebesar 66,1-76,2\% dibanding stimulan etefon $\mathrm{S} / 4 \mathrm{U}$ d3 $6 \mathrm{~d} / 7$ ET2,5\% 20/y (2w). Berdasarkan hasil pengamatan terhadap produksi, kondisi fisiologis, dan kesehatan tanaman, pengisian gas ke dalam aplikator dilakukan setiap 2 minggu dan panel dipindahkan setiap 3 bulan untuk menghindari menurunnya produksi akibat "kelelahan" panel sadap.

Katakunci: Hevea brasiliensis, lateks, sistem sadap, stimulan gas, produksi, kondisi fisiologis, etilen, etefon

\section{PENDAHULUAN}

Perkembangan harga karet yang berfluktuasi dan biaya produksi yang meningkat merupakan kendala tersendiri dalam perkebunan karet. Oleh sebab itu, efisiensi dalam sistem eksploitasi merupakan usaha untuk mengoptimalkan keuntungan. Salah satu cara dengan aplikasi stimulan untuk peningkatan produksi lateks. Stimulasi yang dikombinasikan dengan sistem sadap berintensitas rendah diharapkan dapat menurunkan biaya sadap. Di samping itu perlu adanya pengaturan frekuensi pemberian stimulan berdasarkan tipe dan potensi produksi klon.

Penggunaan stimulan etefon atau gas etilen telah banyak diterapkan secara luas terutama oleh perkebunan karet besar untuk meningkatkan produksi lateks. Stimulan dapat meningkatkan produksi lateks dengan cara memperlama aliran karena penyumbatan pembuluh lateks terhambat (Jacob et al., 1989; Wargadipura, 1981; Krishnakumar et al., 2011 ). Terhambatnya penyumbatan pembuluh lateks merupakan akibat dari peningkatan kestabilan lutoid sebagai respons terhadap etilen (Coupe dan Chrestin, 1989). Stimulan mempengaruhi metabolisme sel lateks, yang tampak dari berbagai perubahan karakter fisiologi antara lain kadar sukrosa, fosfat anorganik, tiol, dan kadar karet kering (KKK) (d'Auzac dan Jacob, 1984; Gohet et al., 2008). Sukrosa merupakan bahan baku dari sintesis cis-poliisoprena, yang dibutuhkan oleh sel lateks untuk regenerasi lateks. (Gohet et al., 2003). Kadar fosfat anorganik menunjukkan intensitas aktivitas metabolisme dalam pembuluh lateks (Lacote et al., 2010). Kadar tiol merupakan parameter yang berkaitan dengan antioksidan yang mencerminkan kemampuan tanaman (active oxigen species) untuk mencegah kerusakan sel oleh radikal bebas (Jacob et al., 1998). Serres et al. (1990) menyatakan tiol melindungi membran dari partikel subseluler dan sebagai agen anti-senescence. Selanjutnya KKK mencerminkan kemampuan tanaman karet untuk meregenerasi lateks (Jacob et al., 1989).

Stimulan yang berbahan aktif etefon dalam tanaman karet akan terhidrolisis menjadi etilen, asam hidroklorit, dan asam fosfat. Setelah etefon diaplikasikan pada alur sadap, etefon tersebut terhidrolisis menjadi etilen. Efektivitas etefon dapat dideteksi dalam waktu 5 sampai 6 jam setelah aplikasi. Oleh karena stimulan dengan bahan aktif etefon berpengaruh tidak langsung, peningkatan produksi hanya mencapai kurang dari 50\% (Yew, 1998). Sebaliknya stimulan dengan bahan aktif gas etilen diserap langsung oleh tanaman karet dengan jumlah yang lebih banyak (Gomez, 1983). Karyudi et al. (2006) menyatakan bahwa penggunaan stimulan gas etilen dapat meningkatkan produktivitas rata-rata sekitar 75 - 100\% diatas sistem sadap konvensional yang dikombinasikan dengan stimulan etefon.

Penelitian ini bertujuan untuk mengetahui pengaruh stimulan gas terhadap produksi, karakter fisiologi, pertumbuhan vegetatif, dan kepekaan klon BPM 24 terhadap kering alur sadap. 


\section{BAHAN DAN METODE}

Penelitian dilaksanakan di Kebun Percobaan Balai Penelitian Sembawa mulai Oktober 2010 sampai September 2011. Penelitian disusun berdasarkan Rancangan Acak Kelompok dengan lima perlakuan sistem sadap dan empat ulangan. Tiap plot terdiri atas 20 pohon. Percobaan menggunakan klon BPM 24 tahun tanam 1997 (berumur 13 tahun) yang ditanam dengan jarak tanam $7 \mathrm{~m} \times 3 \mathrm{~m}$. Penyadapan telah dilakukan sejak 2002 sampai sebelum dilakukan penelitian ini pada B0-1 dan BO-2 dengan sistem sadap $\mathrm{S} / 2$ d3 ET2,5\% 10/y(m). Perlakuan adalah sebagai berikut :

1. S/4 U d3 6d/7ETG $40 / y(w)$

2. S/4 Ud3 6d/7ETG 20/y (2w)

3. S/4 Ud3 6d/7ETG $10 / \mathrm{y}(\mathrm{m})$

4. S/4 U d3 6d/7ET2,5\% 40/y (w)

5. S/4 U d3 6d/7ET2,5\% 20/y (2w) (kontrol)

Aplikasi stimulan gas dipasang pada setiap pohon dengan cara sebagai berikut : bidang sadap dibagi menjadi empat bagian (S/4). Aplikator gas dipasang pada posisi 20 $30 \mathrm{~cm}$ di atas bidang sadap dan $5-7 \mathrm{~cm}$ ke kiri. Gas etilen diaplikasikan sesuai dengan perlakuan. Gas etilen dimasukkan dengan membuka penutup pada selang aplikator dan gas tersebut akan ditampung dalam kantong penampung gas sebelum diserap oleh tanaman (Gambar 1).
Pengamatan dilakukan terhadap peubah produksi (lateks dan lump), kadar karet kering lateks, kadar sukrosa, kadar fosfat anorganik, kadar tiol, lilit batang, dan intensitas kering alur sadap. Pengamatan produksi dilakukan setiap hari sadap, sedangkan lilit batang dan kering alur sadap masing-masing setiap 6 bulan dan 3 bulan. Pengambilan sampel lateks untuk diagnosis lateks dilakukan tiap 3 bulan.

Produksi karet ditimbang sebagai lateks dan lump mangkok. Kadar karet kering (KKK) diukur dengan metode gravimetri, berdasarkan perbandingan \% bobot kering dengan bobot basah lateks sebanyak 5 gram. Pengeringan dilakukan dengan oven suhu $100^{\circ} \mathrm{C}$ hingga bobotnya tetap.

Kadar sukrosa, fosfat anorganik, dan tiol diukur di laboratorium dengan menggunakan spektrofotometer, masingmasing absorbansi diukur pada panjang gelombang 627, 750, dan $412 \mathrm{~nm}$. Setiap sampel lateks $(1 \mathrm{ml})$ diambil dan dipreparasi ke dalam $9 \mathrm{ml}$ TCA 2,5\% (asam trikloro asetat) menjadi serum TCA. Pengukuran kadar sukrosa lateks menggunakan metode anthrone (Dische, 1962). Kadar fosfat anorganik berdasarkan pengikatan oleh ammonium molibdat yang kemudian tereduksi oleh $\mathrm{FeSO}_{4}$ dalam reaksi asam (Taussky dan Shorr, 1953). Kadar tiol

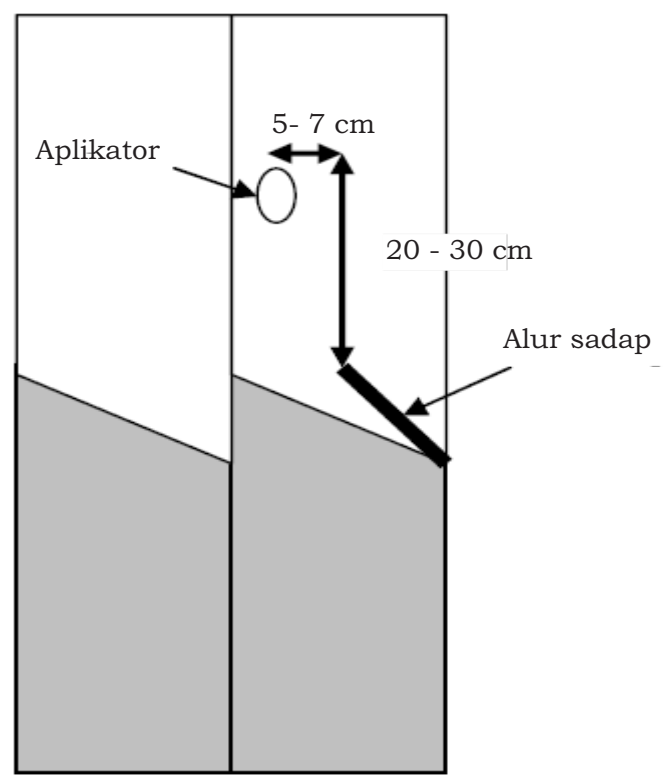

Gambar 1. Pemasangan aplikator dengan sistem Hevea 3 Figure 1. Installation of the system of Hevea 3 applicator 
diukur berdasarkan prinsip reaksinya dengan asam dithiobisnitrobenzoat (DTNB) yang membentuk TNB yang berwarna kuning pada panjang gelombang $412 \mathrm{~nm}$ (McMullen, 1960).

Lilit batang diukur pada ketinggian $100 \mathrm{~cm}$ di atas pertautan okulasi (dpo). Pengamatan persentase kering alur sadap (KAS) dilakukan secara visual, kemudian diubah dengan penilaian skor sebagai berikut :

$0=$ tidak terjadi KAS

$1=1-25 \%$ alur sadap kering

$2=26-50 \%$ alur sadap kering

$3=51-75 \%$ alur sadap kering

$4=76-100 \%$ alur sadap kering

\section{HASIL DAN PEMBAHASAN}

Produksi karet kering pada stimulan gas terbukti lebih tinggi dibandingkan dengan stimulan etefon (Tabel 1). Stimulan gas lebih efektif meningkatkan produksi dengan cara mempengaruhi aliran dan regenerasi lateks. Peningkatan produksi disebabkan peningkatan lama aliran lateks sehingga drainase lateks meluas. Kondisi ini berkaitan dengan peningkatan kestabilan lutoid yang menunda proses penyumbatan pembuluh lateks. Salah satu parameter yang berhubungan erat dengan aliran lateks adalah kadar karet kering (KKK) (Jacob et al., 1989; Wargadipura, 1981 ; Krishnakumar et al., 2011; Coupe dan Chrestin, 1989). KKK dan produksi memiliki korelasi yang negatif. KKK pada stimulan gas menunjukkan penurunan yang bervariasi antar frekuensi stimulan. Walaupun demikian secara umum menurunnya kadar karet kering akibat penggunaan stimulan masih dalam batas normal (Thanh et al., 2006). Kondisi tersebut menunjukkan bahwa kemampuan tanaman untuk regenerasi lateks dalam pembuluh lateks belum terganggu.

Pengaruh stimulan gas dalam hal memperlama aliran lateks terlihat pada hasil lateks dan lump (Tabel 2). Hasil lateks dan lump dengan stimulan gas selama 12 bulan lebih tinggi daripada stimulan etefon yang disebabkan lateks menetes lebih cepat, namun berakibat KKK menurun. Tampak pada hasil lateks dengan stimulan gas yang meningkat 59,4-71,1\% dan hasil lump meningkat $57,1-94,6 \%$ dibandingkan dengan kontrol (perlakuan 5).

Berdasarkan variasi musiman terlihat bahwa dengan stimulan gas, produksi secara dinamis masih lebih tinggi di tiap bulan dibanding kontrol (Gambar 2). Namun pola produksi tiap bulan dengan stimulan gas

Tabel 1. Produksi dan parameter fisiologi dengan aplikasi stimulan gas selama 12 bulan Table 1. Production and physiology parameters with gas stimulation application for 12 months

\begin{tabular}{|c|c|c|c|c|c|c|c|c|}
\hline $\begin{array}{l}\text { Perlakuan } \\
\text { Treatment }\end{array}$ & $\begin{array}{l}\text { Sukrosa } \\
\text { Sucrose } \\
(\mathrm{mM})\end{array}$ & $\begin{array}{c}\mathrm{Pi} \\
(\mathrm{mM})\end{array}$ & $\begin{array}{c}\text { Tiol } \\
(\mathrm{mM})\end{array}$ & $\begin{array}{l}\text { KAS } \\
\text { Dry } \\
\text { tapping }\end{array}$ & $\begin{array}{l}\text { Lilit } \\
\text { batang } \\
\text { Girth } \\
\text { (cm) }\end{array}$ & $\begin{array}{c}\text { Kadar karet } \\
\text { kering (KKK) } \\
\text { Dry rubber } \\
\text { content (DRC) } \\
(\%)\end{array}$ & $\begin{array}{l}\text { Produksi } \\
\text { (g/p/s) } \\
\text { Production } \\
(g / t / t)\end{array}$ & $\begin{array}{l}\text { Kenaikan } \\
\text { produksi } \\
\text { Increase in } \\
\text { production } \\
(\%)\end{array}$ \\
\hline $\begin{array}{l}\text { S/4 U d3 6d/7 } \\
\text { ETG } 40 / y(w)\end{array}$ & $5,5 \mathrm{~b}$ & $11,4 \mathrm{ab}$ & $0,4 \mathrm{a}$ & 1 & 70,7 a & $29,2 \mathrm{~d}$ & $80,2 \mathrm{a}$ & 172,1 \\
\hline $\begin{array}{l}\text { S/4 U d3 6d/7 } \\
\text { ETG } 20 / y(2 w)\end{array}$ & $5,7 \mathrm{~b}$ & $12,0 \mathrm{a}$ & $0,4 \mathrm{a}$ & 0 & 70,9 a & $30,4 \mathrm{c}$ & 82,1 a & 176,2 \\
\hline 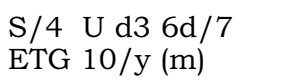 & $6,3 \mathrm{~b}$ & $10,7 \mathrm{abc}$ & $0,4 a$ & 0 & 70,9 a & $32,0 \mathrm{~b}$ & 77,4 a & 166,1 \\
\hline $\begin{array}{l}\mathrm{S} / 4 \text { U d3 6d/7 } \\
\text { ET2,5 \% Ba1(2) } \\
40 / y(w)\end{array}$ & $6,2 \mathrm{~b}$ & $8,6 \mathrm{c}$ & $0,4 \mathrm{a}$ & 0 & 71,8 a & 36,9 a & $51,9 \mathrm{~b}$ & 111,4 \\
\hline $\begin{array}{l}\text { S/4 U d3 6d/7 } \\
\text { ET2,5\% Ba1(2)20/y } \\
\text { (2w) (kontrol) }\end{array}$ & $\begin{array}{l}9,7 \text { a } \\
*\end{array}$ & $\begin{array}{l}9,3 \mathrm{bc} \\
*\end{array}$ & $\begin{array}{l}0,4 \mathrm{a} \\
\mathrm{tn}\end{array}$ & 0 & $\begin{array}{c}72,5 \text { a } \\
\text { tn }\end{array}$ & 37,7 a & $46,6 \mathrm{~b}$ & 100 \\
\hline
\end{tabular}

Angka yang diikuti huruf sama pada kolom sama menunjukkan tidak berbeda nyata pada taraf signifikan $5 \%$ Figures followed by the same letter in the same column were not significantly different at 5\% level

* Kategori KAS (Tapping panel dryness categories): $0 \%=0 ; 1-25 \%=1 ; 26-50 \%=2 ; 51-75 \%=3 ; 76-100 \%=4$

** Jumlah pohon/ha efektif yang disadap 350 pohon dan 100 hari sadap efektif per tahun

The number of trees/ ha effectively tapped was 350 trees with 100 effective tapping days per year 
Tabel 2. Hasil lateks dan lump dengan aplikasi stimulan gas selama 12 bulan Table 2. Latex and cup lump with gas stimulation during 12 months

\begin{tabular}{|c|c|c|c|c|c|}
\hline & $\begin{array}{l}\text { Perlakuan } \\
\text { Treatments }\end{array}$ & $\begin{array}{c}\text { Lateks } \\
(\mathrm{g} / \mathrm{p} / \mathrm{s}) \\
\text { Latex } \\
(\mathrm{g} / \mathrm{t} / \mathrm{t})\end{array}$ & $\begin{array}{c}\% \\
\text { terhadap } \\
\text { kontrol } \\
\% \text { of } \\
\text { control } \\
\end{array}$ & $\begin{array}{l}\text { Lum } \\
(\mathrm{g} / \mathrm{p} / \mathrm{s}) \\
\mathrm{Lump} \\
(\mathrm{g} / \mathrm{t} / \mathrm{t})\end{array}$ & $\begin{array}{c}\% \\
\text { terhadap } \\
\text { kontrol } \\
\% \text { of } \\
\text { control }\end{array}$ \\
\hline $\mathrm{S} / 4$ & U d3 6d/7 ETG 40/y (w) & $\begin{array}{c}47,5 \mathrm{a} \\
(59,2 \%)\end{array}$ & 159,4 & $\begin{array}{c}32,7 \mathrm{a} \\
(40,8 \%)\end{array}$ & 194,6 \\
\hline $\mathrm{S} / 4$ & $\mathrm{U}$ d3 6d/7 ETG 20/y (2w) & $\begin{array}{c}51,0 \mathrm{a} \\
(62,1 \%)\end{array}$ & 171,1 & $\begin{array}{c}31,1 \mathrm{a} \\
(37,9 \%)\end{array}$ & 185,1 \\
\hline $\mathrm{S} / 4$ & $\mathrm{U}$ d3 6d/7 ETG 10/y (m) & $\begin{array}{c}51,0 \mathrm{a} \\
(65,9 \%)\end{array}$ & 171,1 & $\begin{array}{l}26,4 \mathrm{~b} \\
(34,1 \%)\end{array}$ & 157,1 \\
\hline $\begin{array}{l}\mathrm{S} / 4 \\
\mathrm{Ba} 1(2\end{array}$ & $\begin{array}{l}\text { U d3 6d/7 ET2.5\% } \\
\text { 2) } 40 / y(w)\end{array}$ & $\begin{array}{c}34,9 \mathrm{~b} \\
(67,2 \%)\end{array}$ & 117,1 & $\begin{array}{c}17,0 \mathrm{c} \\
(32,8 \%)\end{array}$ & 101,2 \\
\hline $\begin{array}{l}\mathrm{S} / 4 \\
\mathrm{Ba} 1(2\end{array}$ & $\begin{array}{l}\mathrm{Ud} \text { d3 6d/7 ET2.5\% } \\
\text { 2) } 20 / y(2 w)\end{array}$ & $\begin{array}{c}29,8 \mathrm{~b} \\
(63,9 \%)\end{array}$ & 100 & $\begin{array}{c}16,8 \mathrm{c} \\
(36,1 \%) \\
*\end{array}$ & 100 \\
\hline
\end{tabular}

Angka yang diikuti huruf sama pada kolom sama menunjukkan tidak berbeda nyata pada taraf signifikan $5 \%$ Figures followed by the same letter in the same colum were not significantly different at $5 \%$ level

Angka dalam kurung menunjukkan persentase terhadap produksi total

Figures in the brackets showed percentage of total production

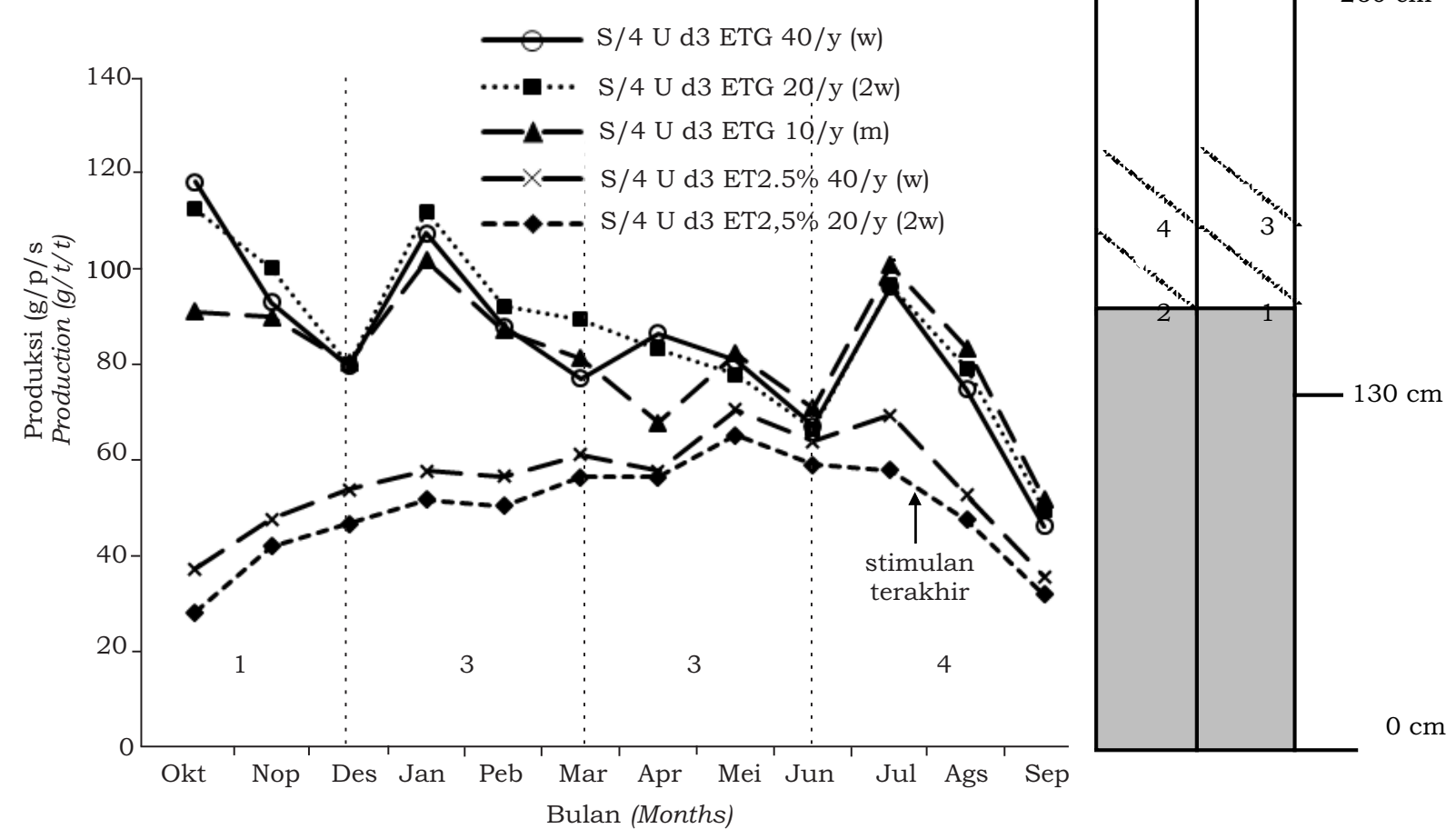

Gambar 2. Pola produksi klon BPM 24 dengan berbagai perlakuan frekuensi stimulan pada tiap panel sadap

Figure 2. Production pattern of BPM 24 clone with various frequency of stimulation at each tapping panel 
tidak stabil dibanding stimulan etefon yang meningkat tiap bulannya. Hal ini ditunjukkan dengan produksi per sadap dengan simulan gas tidak stabil, rataan produksi/bulan cenderung mengalami penurunan (Gambar 3). Penurunan pengaruh penggunaan stimulan gas dan etefon terjadi pada penyadapan ke empat setelah aplikasi. Dengan memperhatikan hal tersebut, maka sebaiknya aplikasi stimulan dilakukan tiap 2 minggu. Di samping itu, dengan stimulan gas nampak rataan produksi bulanan mengalami penurunan (Desember, Maret, Juni). Hal ini diduga adanya keletihan pembuluh lateks. Dengan pemindahan panel setiap 3 bulan maka produksi menjadi meningkat kembali.

Selain itu, pengaruh stimulan gas terhadap regenerasi lateks tercermin pada parameter kadar sukrosa dan fosfat anorganik. Kandungan sukrosa mengalami penurunan dengan penggunaan stimulan gas karena aktivitas metabolisme meningkat
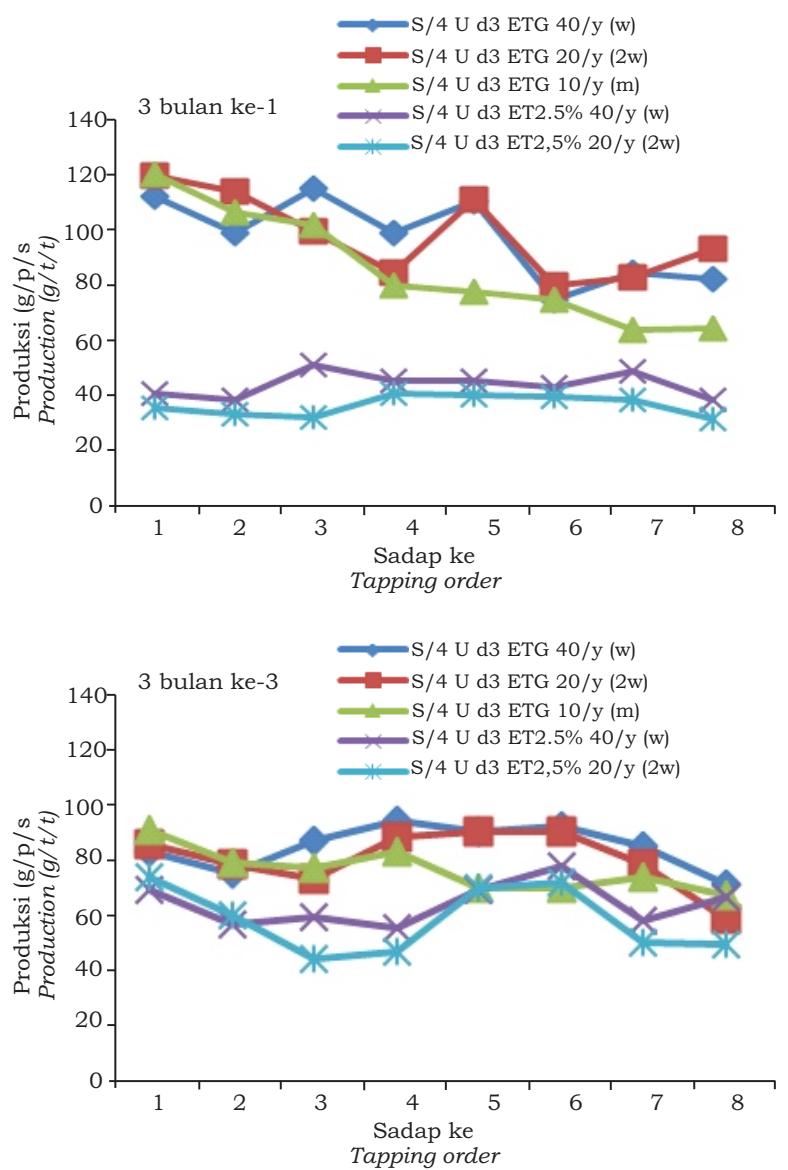

yang tampak pada kandungan fosfat anorganik meningkat. Dengan aplikasi stimulan maka metabolisme sel lateks menjadi aktif untuk meningkatkan produksi (Soumahin et al., 2009). Akibat lanjut dari peningkatan fosfat anorganik adalah peningkatan konsumsi sukrosa dalam proses regenerasi lateks (Gohet et al., 2008). Peningkatan frekuensi stimulan gas dari sekali per bulan menjadi dua kali per bulan masih meningkatkan fosfat anorganik, menurunkan kadar sukrosa lateks, dan meningkatkan produksi sebesar $10 \%$. Namun peningkatan frekuensi stimulan gas dari dua kali per bulan menjadi empat kali per bulan tidak meningkatkan fosfat anorganik meskipun kadar sukrosa menurun. Hal ini kemungkinan adanya keterbatasan suplai sukrosa. Walaupun demikian, aplikasi stimulan gas dengan berbagai frekuensi belum memberikan pengaruh negatif terhadap kondisi fisiologis tanaman karet selama 12 bulan.
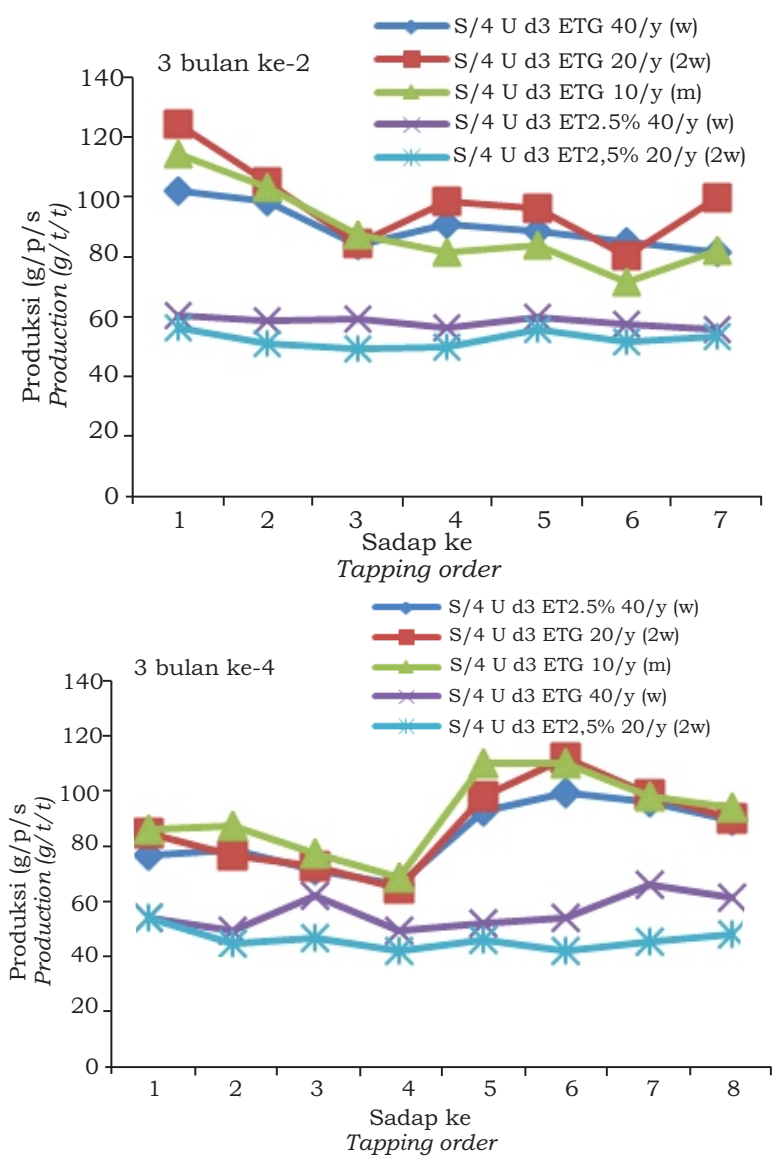

Gambar 3. Pola produksi per sadap pada berbagai perlakuan

Figure 3. Production pattern per tapping on various treatments 
Ditinjau dari kadar tiol, penggunaan stimulan gas tidak memberikan pengaruh yang negatif pada parameter tersebut. Tiol merupakan parameter kontrol dalam hubungannya dengan kering alur sadap (KAS) dan mencerminkan kemampuan tanaman (active oxigen species) untuk mencegah adanya radikal bebas (Jacob et al., 1998). Dengan kadar tiol yang optimum maka intensitas KAS dengan stimulan gas termasuk kategori 0 , kecuali pada $\mathrm{S} / 4 \mathrm{U}$ d3 6d/7 ETG 40/y (w), yang berarti intensitas KAS dengan penggunaan stimulan gas selama 12 bulan masih relatif rendah $(<25 \%)$. Frekuensi stimulan yang tinggi dikhawatirkan dalam jangka panjang menyebabkan gangguan metabolisme dalam biosintesis lateks. Efek lanjut mengakibatkan kelelahan pembuluh lateks (Lacote et al., 2010; Krishnakumar et al., 2011).

Lilit batang tanaman karet tidak terpengaruh dengan penggunaan stimulan gas. Stimulan gas tidak memberikan pengaruh negatif terhadap pertumbuhan tanaman.

\section{KESIMPULAN}

Dengan frekuensi stimulan gas yang tepat diharapkan produksi tanaman karet dapat ditingkatkan tanpa menimbulkan pengaruh yang negatif terhadap kesehatan tanaman. Stimulan gas dapat meningkatkan produksi sebesar 66,1 - 76,2\% dibanding kontrol. Berdasarkan hasil pengamatan terhadap produksi, kondisi fisiologis, dan kesehatan tanaman, pengisian gas ke dalam aplikator sebaiknya dilakukan setiap 2 minggu. Panel harus dipindahkan setiap 3 bulan untuk menghindari menurunnya produksi akibat "kelelahan" panel sadap.

\section{UCAPAN TERIMA KASIH}

Terimakasih kami ucapkan kepada PT Champion Technical Utama atas kerjasamanya yang baik dalam penyediaan sarana penelitian sistem gas.

\section{DAFTAR PUSTAKA}

Coupe, M. and H. Chrestin. 1989. Physicochemical and biochemical mechanism of hormonal (ethylene) stimulation. In Physiology of Rubber Tree Latex.

d'Auzac, and J. L. Jacob. 1984. Physiology of the laticiferus system in hevea nasis and application to productivity. Compte-Rendu du Colloque : Exploitation and Physiology Amelioration. Perancis.

Dische, Z. M. 1962. Carbohydrate Chem. Acad. Press. $1: 488$

Gohet, E., C. Scomparin, E. Cavaloc, Y. Balerin, G. Benites, F. Dumortier, H. Williams, H. P. Permadi, E. Ginting, E. De Rostolan, E. Uche, P. Chegbene, E. Hocepied, P. Echimane, M. Saumahoro, H. J. Sargeant, Suyatno, C. A. Najera, B. Saumahoro, R. Lacote, and J. M. Eschbach. 2008. Influence of ethephon stimulation on latex physiological parameter and conquences on latex diagnosis implementation in rubber agroindustry. IRRDB Workshop : Latex Harvesting Technology.

Gohet, E., P. Chantuma, R. Lacote, S. Obouayeba, K. Dian, A. C. Demange, D. Kurnia, and J. M. Eschbach. 2003. Physiology modelling of yield potential and clonal response to ethephon stimulation. IRRDB Workshop on Exploitation Technology. Kottayam. India.

Gomez, J. B. 1983. Physiology of Latex (rubber) production. Malaysian Rubber Research and Development Board.

Jacob, J. L., J. C. Prevot, D. Roussel, R. Lacrotte, E. Serres, J. d'Auzac, J. M. Eschbach, and H. Omont. 1989. Field limiting factors, latex physiological parameters, latex diagnosis, and clonal typology. In Physiology of Rubber Tree Latex. 
Jacob, J. L., J. C. Prevot, R. Lacote, E. Gohet, A. Clement, R. Gallois, T. Joet, V. Pujade-Renaud, and J. D'Auzac. 1998. The biological mechanism controlling Hevea brasiliensis rubber yield. Plantations, recherche, developpement.

Karyudi, Sumarmadji, dan E. Bukit. 2006. Penggunaan stimulan gas etilen untuk meningkatkan produktivitas tanaman karet. Pros. Lok. Nas. Budidaya Tanaman Karet 2006, 198-207.

Krishnakumar, R, R. L. Helen, P. K. Ambily, dan J. Jacob. 2011. A modified stimulation method in Hevea brasiliensis for reducing oxidative stress. IRRDB International Rubber Conference Thailand, 15 - 16 Dec. 2011.

Lacote, R., O. Gabla, S. Obouayeba, J. M. Eschbach, F. Rivano, K. Dian, and E. Gohet. 2010. Long term effect of ethylene stimulation on the yield of rubber trees is linked to latex cell biochemistry. Field Crops Research. 115, 94-98.

McMullen, A. I. 1960. Thiol of low moleculer weight in Hevea brasiliensis latex. Biochem. Biophys. Acta. 41,152-154.

Serres, E., A. Clement-Vidal, J. C. Prevot., R. Lacrotte, and J. L. Jacob. 1990. Tapping of rubber trees for study of the mechanisms involved in latex production. Physiology and Exploitation of Hevea brasiliensis. Proc. IRRDB Symposium.
Soumahin, E. F., S. Obouayeba, and P. A. Anno. 2009. Low tapping frequency with hormonal stimulation on Hevea brasiliensis clone $\mathrm{PB} 217$ reduces tapping manpower requirement. $J$. Animal and Plant Sciences. 2 (3), 109117.

Taussky, H. H. and E. Shorr. 1953. A micro colorimetric methods for the determination of inorganic phosphorus. $J$. Biol. Chem. 202, 675-685.

Thanh, D. K., N. T. Hoang Van, N. Nang, N. T. H. Thanh, and S. Sivakumaran. 2006. Preliminary results of the application of ethylene gas stimulation (RRIMFLOW) in Vietnam. International Natural Rubber Conference. Ho Chi Minh City, Vietnam.

Wargadipura, R. 1981. Pengujian efikasi stimulan ethrel $2.5 \%$ ready mix pada tanaman karet. Menara Perkebunan. 49 (2), 31-35.

Yew, F. K. 1998. RRIMFLOW system of exploitation recent improvement and update on yield performance. Seminar on Low Intensity Tapping System. 